\title{
小型探査ローバのためのレーザーレンジファインダーによる環境認識
}

\author{
雲 凱 $^{* 1}$, 外本 伸治 ${ }^{* 2}$
}

\section{Environment recognition through laser-range-finder for small exploration rover}

\author{
Kai YUN ${ }^{* 1}$ and Shinji HOKAMOTO ${ }^{* 2}$ \\ ${ }^{{ }_{1},{ }^{* 2}}$ Department of Aeronautics and Astronautics, Kyushu University \\ 744 Motooka, Nishi-ku, Fukuoka 819-0395, Japan
}

\section{Received 6 October 2015}

\begin{abstract}
This paper deals with an environment recognition system which is suitable for small-sized autonomous exploration rovers working on a planet far from Earth. The recognition system consists of a scanning type laser-range-finder and attitude sensors. Because rovers equipped with the proposed system can continue to move on terrains, the system makes it possible for a small sized rover to traverse as a long distance as large rovers under a restriction on its limited mission duration. In this paper the performance of the proposed system is evaluated in both numerical simulations and experiments, considering the effects of sensor errors. Moreover, methods to evaluate estimation accuracy for environmental recognition techniques and to estimate the slip rate of moving rover in short time intervals are introduced.
\end{abstract}

Key words : Exploration rover, Laser-range-finder, Environment recognition, Attitude compensation, Slip rate

\section{1. 緒言}

近年，無人探査ローバによる月や惑星の探査活動についての研究が盛んに行われている（上野，2014）。このよ うな惑星探査ローバによる科学的成果は，大まかにローバの移動距離に比例すると言われている。したがって， 長期間にわたるミッションが可能であれば，科学成果に対する期待も高くなる，その一方で，ロケットの打ち上 げ能力は限られており，探査ローバの大きさや重量には制約が生じる．小型の探査ローバでは，圥長系を構成す る余裕が少なくなり，一般にミッション期間は短くなる.さらに，大型ローバに比べて利用可能なエネルギー量 も少なくなるため，移動速度も遅くなる，そのため，小型の探査ローバが限られたミッション期間の中で大型ロ 一バ並みの移動距離を達成するには，移動していない時間を極力短くすることが必要になる.

天体探査ミッションにおいては, 地球と天体までの距離が探査ローバの基本構成を大きく変える要因となる. 月のように地球から比較的近い天体における探査ローバでは，通信時間・通信量の制限が少なく地上からの遠隔 操縦も可能である。これに対し，遠方の天体における探査ローバでは通信時間が非常に長くなるため，地球から の遠隔操作による移動探査は現実的ではない. 例えば，火星と地球との通信遅れは数分〜数十分であり，データ 通信速度もかなり小さくなる。そのため，地球から遠い天体での探査ローバにとっては，オンボードのコンピュ ータで短時間に計算処理ができるような自律移動システムが望ましい.

探査対象の天体表面は, 一般に石や柔軟な土壌などが存在する未知の不整地であり, 精密な地図も存在しない. したがって，探査ローバが移動する際には自らが計測したデータから周囲の環境情報を取得・整理し，それらの 情報 (傾斜, 障害物, 太陽方向など) を指標として移動方向・移動量を決定する. Goldberg ら (Goldberg et al., 2002) および Cheng ら（Cheng et al., 2006）は，カメラ画像を用いた火星探査ローバのナビゲーションについて研究を行 っている. Li ら (Li et al., 2005) は，火星探査ローバ Spirit/ Opportunity に適用されたカメラによる自律移動の結果

\footnotetext{
No.15-00550 [DOI:10.1299/transjsme.15-00550], J-STAGE Advance Publication date : 10 February, 2016

*1 九州大学大学院, 工学府 (T819-0395 福岡県福岡市西区元岡 744)

*2 正員, 九州大学大学院, 工学研究院

E-mail of corresponding author: hokamoto@aero.kyushu-u.ac.jp
} 
をまとめて報告している，これらの手法では，画像から特徵点を抽出し，また複数の画像で対応付けを行うとい ったデータ処理を行っており, 非常に多くの計算を必要としている. しかし, 温度や宇宙線などの過酷な宇宙環 境でも誤動作しないことを保証した計算機の性能は一般に低く，探査ローバに搭載されたオンボードコンピュー タが大量の計算を短時間で処理することは難しい，そのため現在の宇宙探査ミッションでは，得られた画像を地 球に伝送し地上の高性能コンピュータで処理することが多いが, このことはデータの送受信に必要な時間の間, ローバは止まったままでコマンドを待つことを意味する．カメラ画像を用いた高速ナビゲーションの研究も行わ れている（國井, 2012）が，高速処理と高精度を両立させることは容易ではない.

カメラのほかに環境認識のためによく用いられるセンサーとしては, レーザーレンジファインダー（Laser Range Finder，LRF）が挙げられる. Wulfら（Wulf et al., 2003）および Nguyen ら（Nguyen et al., 2005）は，室内 の整地において, LRFによる自律移動ロボットに関する研究を行っている. Thrun ら（Thrun et al., 2003）は, LRF を用いて不整地における三次元環境の再構築の研究をしているが，システムの移動は考慮していない．未知の屋 外不整地における自律移動に関する研究は, Surmann ら（Surmann et al., 2004）や Nuchter ら（Nuchter et al., 2004） によって行われた. 彼らは 2 地点で得られた LRF のデータから移動量を推定する手法について研究しているが, 環境データを取得する間, ローバは止まった状態である.

LRF による三次元環境認識では, カメラ画像での特徵点抽出や対応付けなどの複雑な計算処理を必要としない が，レーザーを二次元方向にスキャンする必要がありそのために数秒〜十数秒の時間を要することが最も本質的 な問題となる．これは，表面までの距離データを得た時刻が異なることを意味し，そのためLRFによるスキャン の間，ローバは止まっていることが前提となっている．特に天体探査ローバでは，表面が不整地であるために， 移動しながらのスキャンではレーザーの照射方向が表面傾斜の影響を受けてしまう. そこで本研究では, 姿勢セ ンサーを用いて移動中のローバの傾きを計測することでLRF の照射方向を補正し，ローバが移動しながらでも三 次元地形を精度よく再構成する方法について研究する.これにより, 探査ローバはそのミッション期間の大半に おいて移動し続けることが可能になり，ミッション期間が短い小型ローバであっても大型ローバ以上の距離を走 破・探査することが可能になる. (なお現在, レーザーを二次元に照射し, 瞬時に三次元環境を認識するフラッシ ユライダーと呼ばれるシステムの研究開発も行われている. しかしその解像度は, 本研究で用いるスキャン型LRF に比べて格段に低く，現時点では環境を精度よく認識することはできない.）

また LRF による環境認識をカメラ画像に基づくシステムと比較すると, LRF からは表面の色やテクスチャーと いう情報が得られないという問題がある. 天体表面は，レゴリスという非常に細かい砂で覆われた軟弱土壌があ ることも多く，ローバがスタックしないようにする必要がある. 表面の色やテクスチャーの情報は, 土壤の滑り 易さやぬかるみ易さの判定に用いることができる（Bell et al., 2003）が，LRF での環境認識ではそのような情報 が得られないことになる. そこで本研究では, 再構成された表面データからローバの移動距離を推定し, “移動し たはずの距離”と “実際に移動した距離” の違いから滑り率を監視するシステムを提案する. これにより滑り率 が大きくなっていると判定できれば，完全にスタックして動けなくなる前に後退・進路変更により，ローバがス

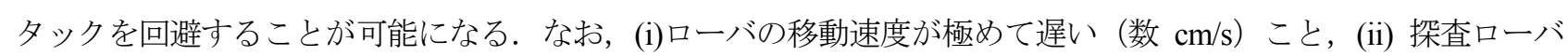
では緩く堆積した車輪直下の土壌が変形・崩壊すること，のために加速度計を用いた手法やデッドレコニング等 を用いた手法で滑り率を推定することは極めて困難である.

本論文において検討する探查システムでは，ローバは LRF スキャン中も止まらず移動し続ける，そのために， スキャン型 LRF と姿勢センサーを併用した環境認識システムを考え, 姿勢センサー誤差を考慮した上で, システ ムの性能を計算機シミュレーションおよび実験より定量的に評価・検証する.このとき推定精度は, 探査システ ムとして想定されているローバの大きさやLRF の仕様に影響される．そこで，宇宙航空研究開発機構（JAXA） で検討されている探査ミッション (大槻他, 2012) に基づき同等の自律探査ローバの大きさや環境認識システムを 設計・製作した. また, 推定精度を定量的に評価する手法について説明する. 以上を 4 章までに述べる. さらに, ローバが静止して LRF スキャンした後に一定の距離を移動し，再びローバを静止させ LRF スキャンをするとい う一般的な方法では移動中にローバが完全にスタックしてしまう危険性がある.そこで 5 章において, 移動中の ローバで得られた LRF のスキャンデータから滑り率を推定する方法について検討する. 


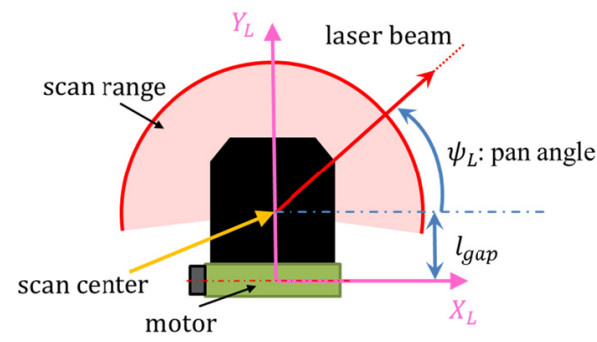

(a) Top view

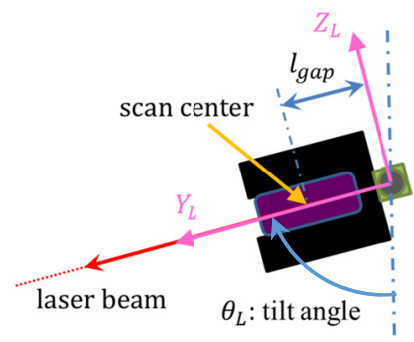

(b) Side view

Fig. 1 Definitions of the directions of scan angles and the coordinate system.

Table 1 Specifications of the LRF sensor

\begin{tabular}{|c|c|}
\hline \multicolumn{2}{|c|}{ [Scanning for the pan directional rotation] } \\
\hline scan range & $190[\mathrm{deg}]$ \\
\hline resolution & $0.25[\mathrm{deg}]$ \\
\hline scan time for each rotation & $50[\mathrm{~ms}]$ \\
\hline \multicolumn{2}{|c|}{ [Scanning for the tilt directional rotation] } \\
\hline scan range & 20 90 [deg] \\
\hline resolution & $0.35[\mathrm{deg}]$ \\
\hline scan time for the full range & $10[\mathrm{~s}]$ \\
\hline
\end{tabular}

\section{2. 小型自律探査ローバシステム}

前章でも述べたように，地球から遠い天体の探査を地上からのコマンドで実施しようとすれば，探査ローバは ミッション時間のほとんどを待ち時間として費やしてしまう。例えば，火星からの画像を周回軌道上の中継器を 介して地球まで送る場合, 数分以上の通信時間遅延のほかに, ローバー中継器間の低い通信速度や地上での処理 に要する時間も必要であり，加えて地球や火星の自転に伴う通信リンクが取れる時間帯にも制約が生じる．その 結果，火星探査ローバはコマンドを受信できる回数が 1 日あたり $3 \sim 5$ 回程度となり，コマンドごとに $10 \mathrm{~m}$ 程度 移動するとしても 1 日の移動距離は数十 $\mathrm{m}$ にとどまる.これに対しローバがオンボードセンサーに基づき自律的 に移動し続ける場合, 通信リンクの制限から例えば移動時間を 1 日に 3 時間とし, 移動速度を $2 \mathrm{~cm} / \mathrm{s}$ として, 1 日に移動可能な距離は $216 \mathrm{~m}$ となり, 現在の火星探査ローバの数倍になる.

探査ローバシステムの性能を考慮する場合, ハードウェアの性能やローバサイズがシステム全体の性能に大き く影響する，そこで，以下ではJAXA で検討されているシステムに基づき製作した自律探查ローバ実験機につい て説明し，それに基づいた性能を次章以降で議論する.

\section{$2 \cdot 1$ レーザーレンジファインダー(LRF)}

搭載されるスキャン型LRF としては, 北陽電機の UXM-30LX-EW を用いる.レーザーの波長は $905 \mathrm{~nm} て ゙ あ り ，$ パン方向（垂直軸まわりの回転方向）に毎秒 20 回転し，進行方向を中心とした 190 度の範囲において 0.25 度間 隔でレーザーを照射する.さらにこの LRF センサーを, 外部に取り付けたモーターによりチルト方向 (上下方向) に回転させることで，二次元のスキャンを実現する（図 1). 仮に，チルト方向の角度 $\theta_{L}=20 \sim 90$ 度を 7 度 /秒 で回転させると，全体のスキャンに要する時間は 10 秒， $\theta_{L}$ 方向の分解能は 0.35 度となる. このとき，LRFより $10 \mathrm{~m}$ 離れた地点における分解能は, パン方向とチルト方向にそれぞれ $4.4 \mathrm{~cm}$ と $6.1 \mathrm{~cm}$ であり, カメラ画像に比 べると分解能は低いが，ローバにとって致命的な危険を及ぼす障害物などを発見するのには十分な精度である. LRF の諸元を表 1 に示す. 
Table 2 Specifications of the developed rover system and the mounted sensors

\begin{tabular}{|c|c|}
\hline \multicolumn{2}{|l|}{ [Size of the rover system] } \\
\hline wheel tread (width) & $0.54[\mathrm{~m}]$ \\
\hline wheel base (length) & $0.8[\mathrm{~m}]$ \\
\hline diameter of a wheel & $182[\mathrm{~mm}]$ \\
\hline \multicolumn{2}{|l|}{ [Laser Range Finder, LRF] } \\
\hline Mounted height & $1.48[\mathrm{~m}]$ \\
\hline \multicolumn{2}{|l|}{ [Attitude sensor] } \\
\hline accuracy for attitude sensing & $\pm 1[\mathrm{deg}]$ \\
\hline sampling rate & $50[\mathrm{~Hz}]$ \\
\hline
\end{tabular}

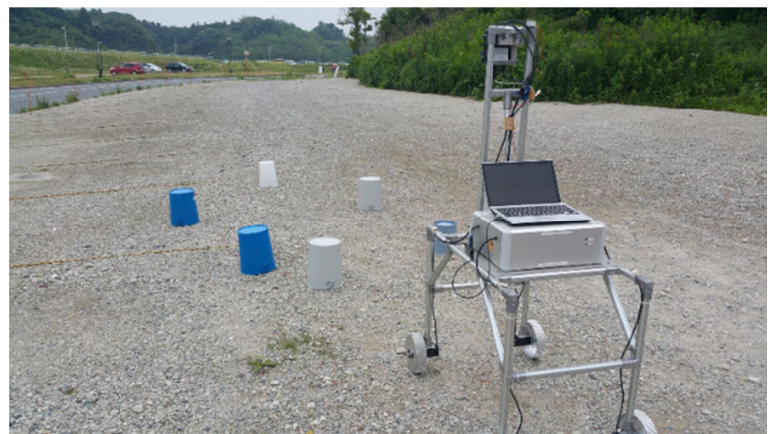

(a) Snapshot of an experiments using a rover

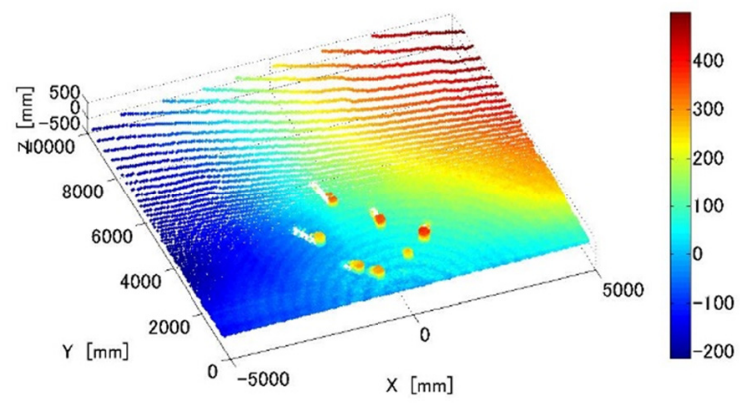

(b) Terrain surface reconstructed in an experiment

Fig. 2 Developed autonomous rover and an example of obtained terrain surface

\section{$2 \cdot 2$ ローバシステム}

天体探查ローバには，エネルギー効率の観点から車輪移動型が採用される場合が多い. 車輪移動型のローバの 姿勢変動量は，表面の凹凸以外にローバおよび車輪のサイズに依存する．ここでは，JAXA において検討されて いる探査ローバ (Micro-6) の諸元をもとにして, 表 2 に示寸諸元を有する実験機を製作した. 四つの車輪は, 車 輪に直に接続されているモーターにより，独立に回転量を調整できるようになっている．また，自律探査ができ るように，PC およびセンサー・バッテリー等も搭載されている. 表 2 には，ローバのほかに，LRF の取り付け 位置と姿勢補正のために用いるセンサーAMU-3002B Lite の精度も示寸. 図 2(a)は実験の様子であり, (b)は LRF により推定された表面凹凸の一例である. 図 2(b)の $X$ 方向に連なる点群はレーザーが 1 回転する間に得られた データであり，本論文ではこの線状データをスキャンラインと呼ぶ。 なお，実験において再構成される地表面の 座標データは，一般にローバを中心とした扇形となるが，その範囲は地面の起伏やローバ姿勢にも影響される. そこで本論文では，同じ領域で推定精度を比較するために，実験から得られるデータは矩形領域のみを示し，推 定精度の評価もこの範囲内のデータだけで定量化する.

\section{3. 計測データの補正に関する予備検証}

\section{$3 \cdot 1$ 姿勢補正の手法}

探査ローバが不整地を移動しながら LRF による計測を続ける場合, レーザーの照射方向は表面傾斜の影響を受 ける. スキャン型の LRFによる三次元推定では, 取得した距離データに同時刻性がないため, 表面傾斜によるレ 一ザー照射方向のずれを補正することが必要である。このために，ローバに搭載した姿勢センサーの情報を利用 する. 図 3 は, LRF で計測されたローカル座標 $X_{L} Y_{L} Z_{L}$ でのデータをローバ固定座標系 $X Y Z$ での位置データに変 換する際に用いる座標系と角度を示す. まず, LRF で得られた距離データは, パン角 $\psi_{L}$ とチルト角 $\theta_{L}$ を用いて, 


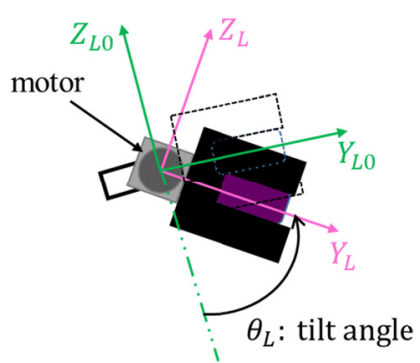

(a) Extended view of LRF

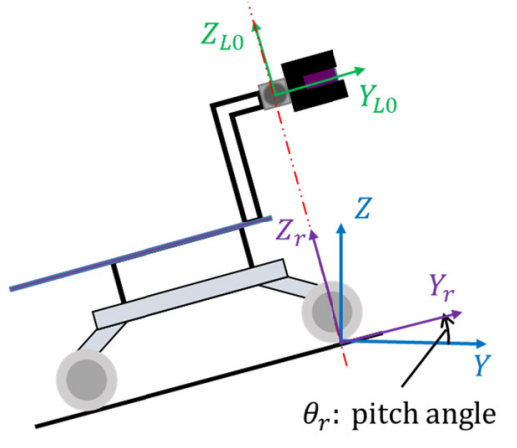

(b) Side view

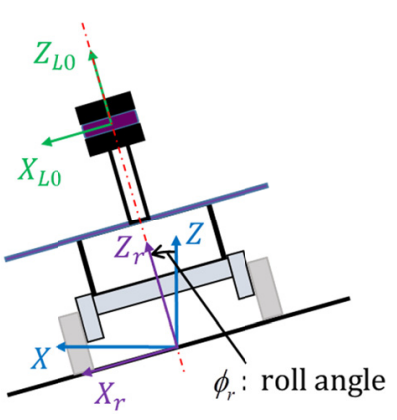

(c) Front view

Fig. 3 Definitions of the coordinate systems and angles

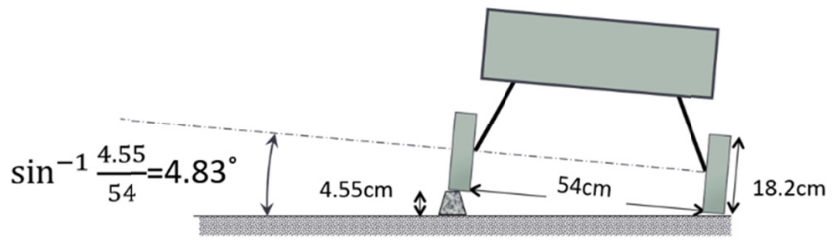

Fig. 4 Attitude deviation due to an obstacle

$\mathrm{LRF}$ 座標系 $X_{L 0} Y_{L 0} Z_{L 0}$ で表現する. このとき, 図 1 中のパン方向回転中心と $X_{L 0} Y_{L 0} Z_{L 0}$ の原点との距離 $l_{g a p}=101.5$ $\mathrm{mm}$ による並進移動の影響も含める. 続いて, 探査ローバの前輪接地点の中心に定義したローバ座標系 $X_{r} Y_{r} Z_{r}$ で のデータに (並進) 変換する.さらに, ローバに搭載された姿勢センサー出力（ピッチ角 $\theta_{r}$, ロール角 $\phi_{r}, \exists ー$ 角 $\psi_{r}$ ）を使って，水平面状にある（仮想的な）ローバを想定したローバ固定座標系 XYZ における三次元位置デ 一タに変換する．ただし，探査ローバの移動速度は極めて遅く（一般に $5 \mathrm{~cm} / \mathrm{s}$ 以下）またパン方向のスキャンは 1 秒間に 20 回転であるために, 1 回転の間の姿勢変更はないと仮定する. この一連の変換において, LRF 距離デ 一タから $X_{L 0} Y_{L 0} Z_{L 0}$ 座標系への変換とローバ座標系 $X_{r} Y_{r} Z_{r}$ からローバ固定座標系 $X Y Z$ への変換は連続した回転 変換であり, Roll $\rightarrow$ Pitch $\rightarrow$ Yaw の順番での回転させる. $\sin (\alpha) \rightarrow s_{\alpha}, \cos (\alpha) \rightarrow c_{\alpha}$ とするとき, 変換行列は次式 のように計算される.

$$
\begin{aligned}
R_{r p y}=\operatorname{Rot}(Z, \psi) \operatorname{Rot}(Y, \theta) \operatorname{Rot}(X, \phi) & =\left[\begin{array}{ccc}
c_{\psi} & -s_{\psi} & 0 \\
s_{\psi} & c_{\psi} & 0 \\
0 & 0 & 1
\end{array}\right]\left[\begin{array}{ccc}
c_{\theta} & 0 & s_{\theta} \\
0 & 1 & 0 \\
-s_{\theta} & 0 & c_{\theta}
\end{array}\right]\left[\begin{array}{ccc}
1 & 0 & 0 \\
0 & c_{\phi} & -s_{\phi} \\
0 & s_{\phi} & c_{\phi}
\end{array}\right] \\
& =\left[\begin{array}{ccc}
c_{\theta} c_{\psi} & -c_{\theta} s_{\psi} & s_{\theta} \\
s_{\phi} s_{\theta} c_{\psi}+c_{\phi} s_{\psi} & -s_{\phi} s_{\theta} s_{\psi}+c_{\phi} c_{\psi} & -s_{\phi} c_{\theta} \\
-c_{\phi} s_{\theta} c_{\psi}+s_{\phi} s_{\psi} & c_{\phi} s_{\theta} s_{\psi}+s_{\phi} c_{\psi} & c_{\phi} s_{\theta}
\end{array}\right]
\end{aligned}
$$

\section{$3 \cdot 2$ 計算機シミュレーションによる検証}

まず，姿勢センサーによるローバ姿勢補正の効果を計算機シミュレーションにより検証するために，以下のよ うな条件を設定する，なお，設定した理由は後に示す．

表面 : 最大で \pm 5 度の起伏をもつランダムな不整地で, 高さ数十センチ程度の突起を複数配置

探査ローバ : 移動速度 $2 \mathrm{~cm} / \mathrm{s}$, 土壌表面と車輪との間の滑りなし

スキャン範囲 : LRF のチルト角 $\theta_{L}$ が 7 度 / 秒で 30 度から 60 度まで変化

姿勢センサー : 誤差なし (図 5), 誤差あり（最大誤差 : $\pm 1 \mathrm{deg}, \pm 2 \mathrm{deg}, \pm 3 \mathrm{deg} の 3$ 種類） 


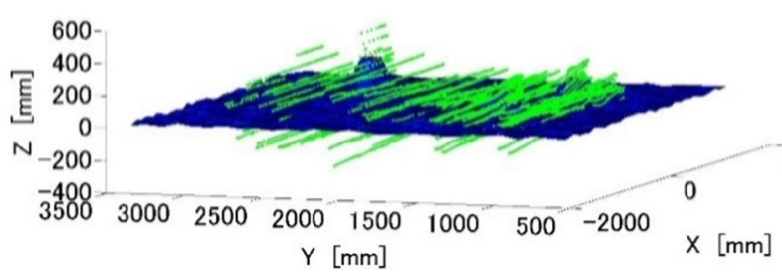

(a) Estimated terrain without compensation (aerial view)

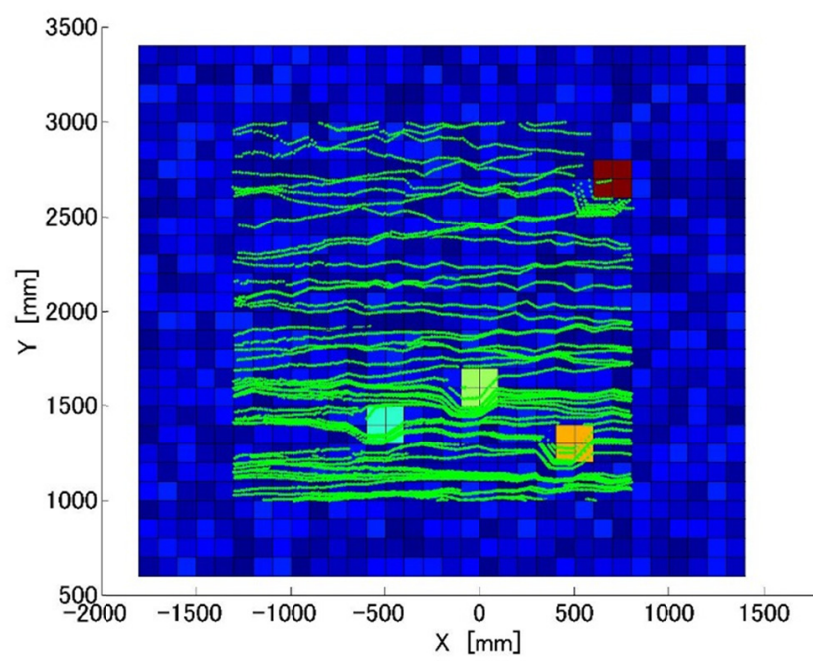

(b) Estimated terrain without compensation (top view)

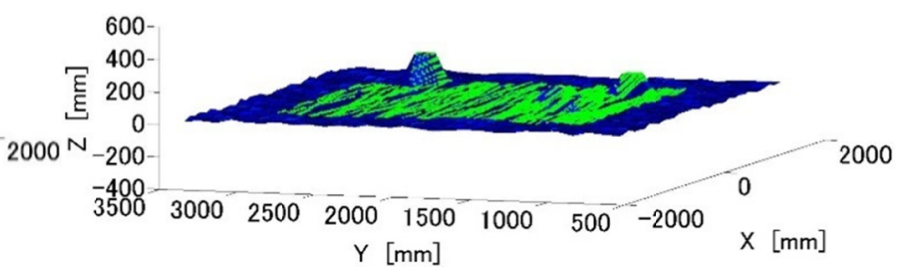

(c) Estimated terrain with compensation (aerial view)

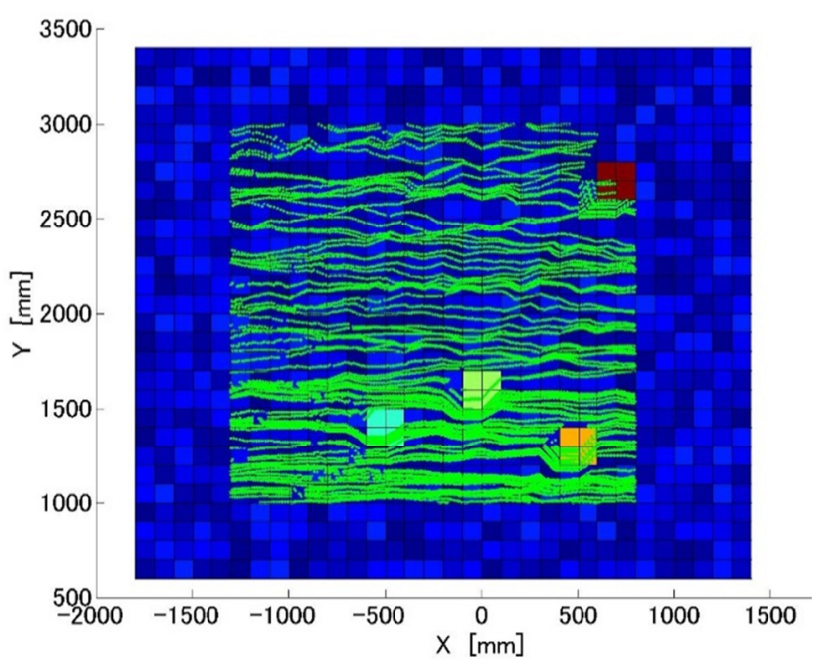

(d) Estimated terrain with compensation (top view)

Fig. 5 Comparison of the results with and without attitude compensation

不整地における凹凸に伴うローバの姿勢変動は，ローバ車輪の乗り越え能力に依存する．車輪が乗り越えられる 障害物は，理論的な上限が車輪直径の半分で実際には 4 分の 1 程度とされる。したがって，実験機の車輪直径が $18.2 \mathrm{~cm}$ であれば, $4.55 \mathrm{~cm}$ 程度の障害物が乗り越えられることになる．このときローバ実験機では，前後の車輪 間距離（ホイールベース）よりも左右の車輪間距離（トレッド）が短いため，障害物乗り越えに伴う姿勢変動量 （ロール角）は，図 4 のように，およそ 5 度弱と予想される，そこで，最大で \pm 5 度の起伏をもつランダムな不 整地を想定し，ローバはこの不整地を移動すると考える．先に述べたように，ローバの移動速度は一般に極めて 遅く, 以下では最も代表的な移動速度 $2 \mathrm{~cm} / \mathrm{s}$ を用いて検討寸る. また, 土壤表面と車輪との間の滑りは考えない.

図 5 は, $2 \mathrm{~cm} / \mathrm{s}$ で移動するローバ上の LRF で地表面の形状を推定した結果の一例である（ただし，次章の実験 検証と条件を同じにするために， $X=-1300 \sim 800 \mathrm{~mm}, \quad Y=1000 \sim 3000 \mathrm{~mm}$ だけを抽出している). 図中の濃い 青色はシミュレーションで模擬した表面であり, 乱数を用いて高さ数十センチ程度の突起を複数配置している. ローバが最大 \pm 5 度の起伏を移動するのに伴い，ピッチ角とロール角の両方に姿勢変動が生じることになる．図 中の緑色の点列は, LRF のチルト角 $\theta_{L}$ が 7 度 /秒で 30 度から 60 度まで変化する約 4.3 秒の間に得られたデータ から推定した表面形状を表している. (a)と(b)は姿勢センサーによる補正を行わない場合の鳥瞰図と平面投影図の 結果であり，推定された表面（緑）が表面（青）からずれていることが分かる，一方(c)と(d)は姿勢センサーによ って補正された結果であり，ピッチ角・ロール角に変動が生じても精度よく推定できていることが分かる.

姿勢補正の効果を示すために，図 5 では姿勢角が誤差なく正確に測定できると仮定したが，実際には姿勢セン サーに測定誤差が必ず含まれる．実験機に搭載した AMU-3002B Lite の誤差は，カタログ值として静的状態で精 度 1 度未満であるが，別の姿勢センサーを用いると精度も異なる．そこで，姿勢角詔差が推定精度に及ぼす影響 を計算機シミュレーションによって調べる.ここでは傾向をはっきりさせるために, 姿勢変動の影響受けやすい, より遠くの地表面データで検証する. チルト角 $\theta_{L}=45 \sim 75$ 度における範囲を調べ，姿勢角の影響を除外するた めにローバは停止した状態とする，なお，このチルト角に相当する距離は，ローバから $1.48 \sim 5.04 \mathrm{~m}$ の範囲に相 当する. ピッチ角とロール角の誤差がそれぞれ精度にどのように影響を与えるか検証するため，(i)ピッチ角のみ に誤差を含む場合，(ii)ロール角のみに誤差を含む場合，(iii)両方に誤差を含む場合に分けて検証する．さらに， 


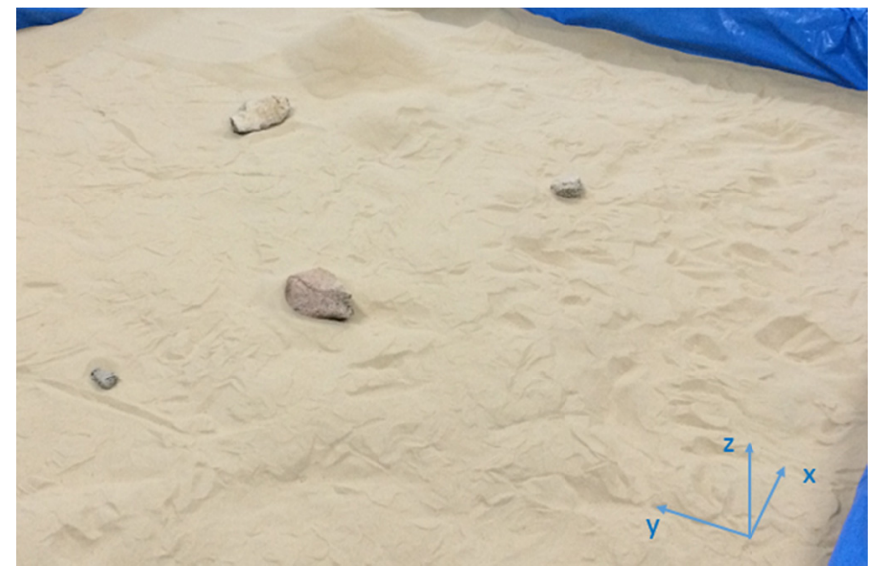

(a) Environment used in experiments

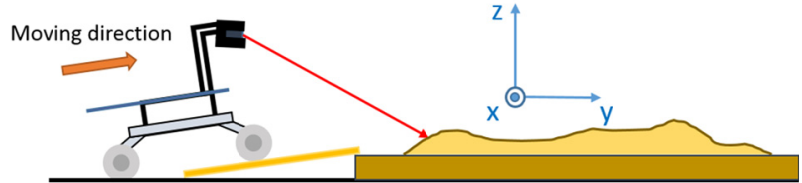

(b) Schematic drawing for experiment 1

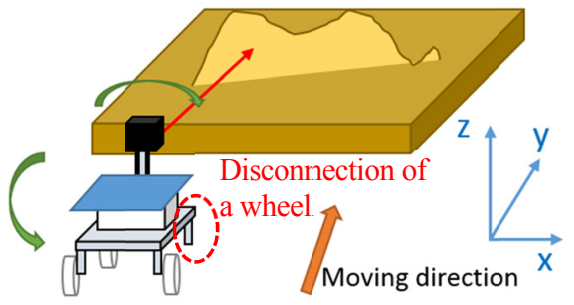

(c) Schematic drawing for experiment 2

Fig. 6 Experiment to evaluate effects of pitch and roll changes

Table 3 The average error for each measuring point [mm].

\begin{tabular}{l|c|c|c}
\hline & Within $\pm 1 \mathrm{deg}$ & Within \pm 2 deg & Within \pm 3 deg \\
\hline (i) Pitch error only & 21.15 & 39.28 & 65.46 \\
\hline (ii) Roll error only & 14.56 & 24.93 & 43.28 \\
\hline (iii) Pitch and Roll error & 27.16 & 50.21 & 82.93 \\
\hline
\end{tabular}

Table 4 Attitude changes during the experiments [deg].

\begin{tabular}{c|c|c|c|c}
\hline \hline & Experiment. 1 (1) & Experiment. 1 (2) & Experiment. 2 (1) & Experiment. 2 (2) \\
\hline Pitch change & $9.5 \sim 10.4$ & $9.8 \sim 11.2$ & $-3.2 \sim 0.2$ & $-3.4 \sim 0.9$ \\
\hline Roll change & 0 & 0 & $-4.1 \sim-0.3$ & $-5.1 \sim-0.2$ \\
\hline
\end{tabular}

姿勢角誤差の範囲として, $\pm 1 \mathrm{deg}$ 内, $\pm 2 \mathrm{deg}$ 内, $\pm 3 \mathrm{deg}$ 内の 3 通りを考える. 乱数を用いて姿勢角誤差を生成 し，それぞれの場合において推定された各点の座標が，誤差を含まない場合に比べてどの程度ずれるかを次式で 評価する.

$$
\sqrt{\left(x_{\text {error }}-x_{\text {truth }}\right)^{2}+\left(y_{\text {error }}-y_{\text {truth }}\right)^{2}+\left(z_{\text {error }}-z_{\text {truth }}\right)^{2}}
$$

結果を，表 3 にまとめる（ここでも次章の実験検証と条件を同じにするために， $X=-1300 \sim 800 \mathrm{~mm}$, $Y=1000 \sim 3000 \mathrm{~mm}$ だけを使って誤差の大きさを評価している). 表より，ロール角のみに誤差がある場合の平 均誤差がピッチ角のみに誤差を含む場合に比べて小さいが, これはロール角誤差の影響が $\operatorname{LRF} の Y_{L}$ 軸 $\left(X_{L}=0\right)$ ではゼロとなり，また軸の近いところでもその影響が小さいためである.

\section{4. 表面形状推定精度についての実験検証}

\section{$4 \cdot 1$ 実験による表面形状の再構成}

計算機シミュレーションでは, センサーのノイズや丸め誤差, また姿勢センサーと LRF の同期誤差などが及ぼ す影響を考慮するのが難しい，そこで次に，計算機シミュレーションの妥当性を検証するために，実験によりス キャン型 LRF による環境認識システムの性能を検証する．以下のような条件で実験を行った.

表面 : 天体表面のモデルとして実験室内に作った砂場（図 6(a)）

探查ローバ : 図 2 に示寸実駚機, 速度 $2 \mathrm{~cm} / \mathrm{s}$ で砂場の外を移動 
実験条件 : ピッチ角のみを変化（実験 1)，ピッチ角とロール角の両方を変化（実験 2） 実験に用いる天体表面は実験室内に作った砂場であり，センサ一関連の誤差が及ぼす影響に注目するために，車 輪と砂表面との間でスリップすることがないよう，ローバは砂場の外を移動しつつ砂場表面の凹凸を計測する. ローバの移動速度は $2 \mathrm{~cm} / \mathrm{s}$ とし，チルト角 $\theta_{L}$ は上方から下方にスキャンする．なお，実験開始時にローバ実験 機がある場所を座標系の原点としている。また実験室内の他設備の影響を除外するために，以下では $X=-1300 \sim 800 \mathrm{~mm}, \quad Y=1000 \sim 3000 \mathrm{~mm}$ の領域について推定した表面の起伏を示す.

実験は二種類行い，実験 1 ではピッチ角のみを変化させ，実験 2 ではピッチ角とロール角の両方を変化させる (それぞれ，前章の計算機シミュレーションの(i)と(iii)に相当する)，実験 1 では，ローバ実験機の前輪だけが一 定の傾斜を持つ平面を移動し, 後輪は水平面上にとどまるようにする (図 6 (b)を参照)。そのため, ローバの移 動に伴い，ピッチ角が常に変化する．このとき左右の前輪はほぼ同じ高さにあるため，ロール角はほとんど変化 しない，一方実験 2 では，ローバ実験機の前輪を一つ外して三輪で水平面を走行させる (図 6 (c) を参照)。この とき重心位置の関係で，ローバは外した車輪の方向に傾こうとするので，手動でローバの姿勢を変化させる．こ の場合，ピッチ角とロール角の両方が変化する.

移動中のローバに搭載された LRF による表面の凹凸推定精度を評価するにあたっては，スキャン型 LRF 自体 の推定性能の限界も重要な要因である. そこで, まずスキャン型 LRFによる推定性能を知るために, ローバが静 止した状態で砂場をスキャンさせて, 表面の凹凸を再構成した（図 7(a)). 実験 1 と実験 2 はそれぞれ二回行い, 各実験において, 姿勢センサーより計測されたローバの姿勢角変動範囲を表 4 に示寸. 図 7(b) と(c) は, 実験 1 に おいて, 姿勢変動の影響を補正しない場合と補正した場合の結果である. なお，図 7(a)〜(e)の右側にあるカラー バーは表面の高さに応じた色を表しているが，(b)だけは高度範囲が違うことに注意されたい. 前輪が傾斜面を登 るためピッチ角は時間に伴い徐々に大きくなるが, 角度変動量が小さいため, ピッチ角誤差の影響は LRF からの 距離が大きい奥側において大きく, 手前側での誤差は相対的には小さくなっている. 図 7(c)は, ピッチ角の補正 をすれば移動しながらの計測実験でも，図 7(a)とほぼ同程度の推定が可能であることを示している. 次に実験 2 において, 姿勢変動の影響を補正しない場合と補正した場合に再構築した結果を図 7(d) と(e)に示す. 姿勢補正を しない場合, 図7(d)において, ローバから見て左側に大きな推定誤差が表れている.これに対し, 図 7(e)に示さ れているように，姿勢角の変動を補正すれば，実験 1 と同様に，推定誤差が大幅に低減化され図 7(a) とほぼ同程 度の推定結果になることが分かる. なお, 図が小さく判別しづらいが, 実験 2 ではロール角に変化が生じるため, スキャンラインは基本的に $X$ 軸に平行ではなく斜めになるが，全体的な形状はよく再構成できている. 


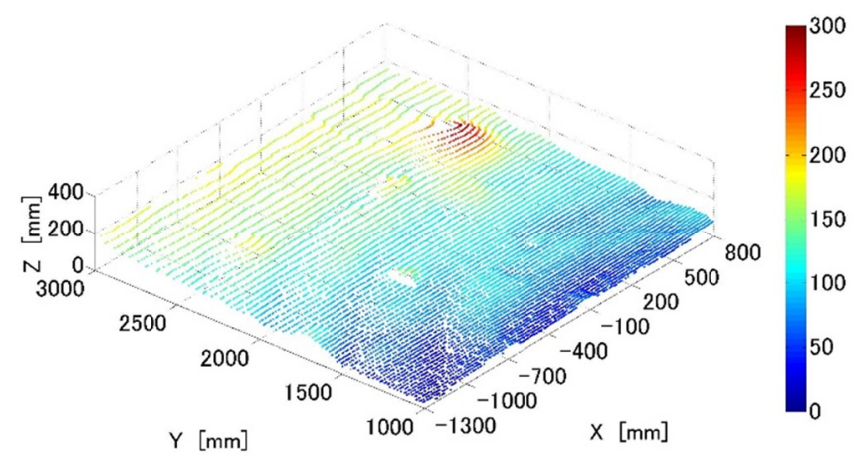

(a) Terrain data obtained on a static rover

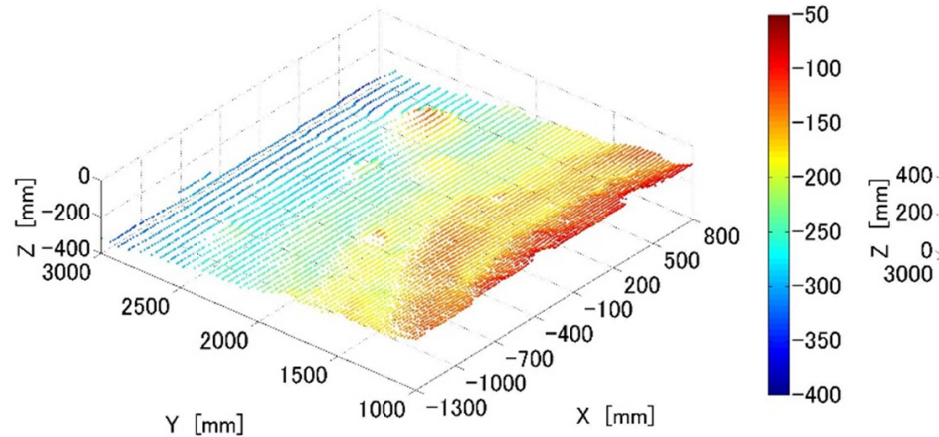

(b) Terrain without compensation in Experiment 1

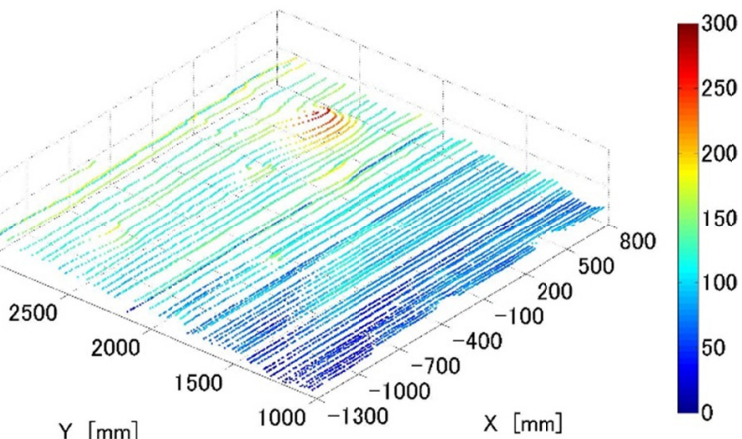

(c) Compensated terrain in Experiment 1

(Note: The scale of height bar is different from others)

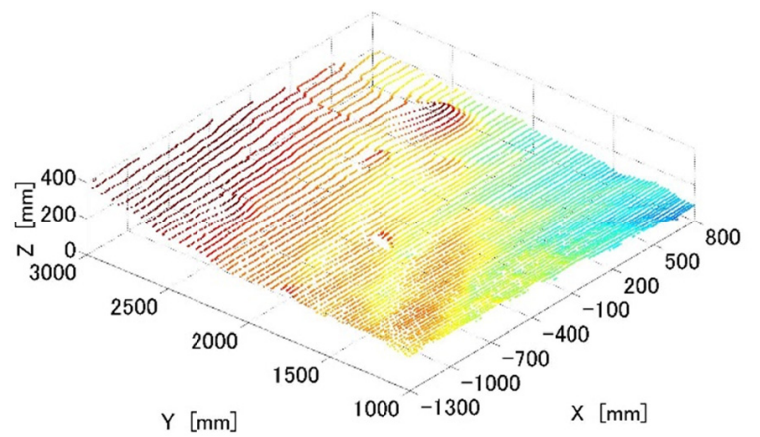

(d) Terrain without compensation in Experiment 2
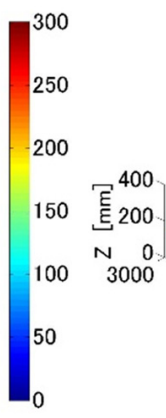

(e) Compensated terrain in Experiment 2

Fig. 7 Comparison of reconstructed terrains in Experiments 1 and 2

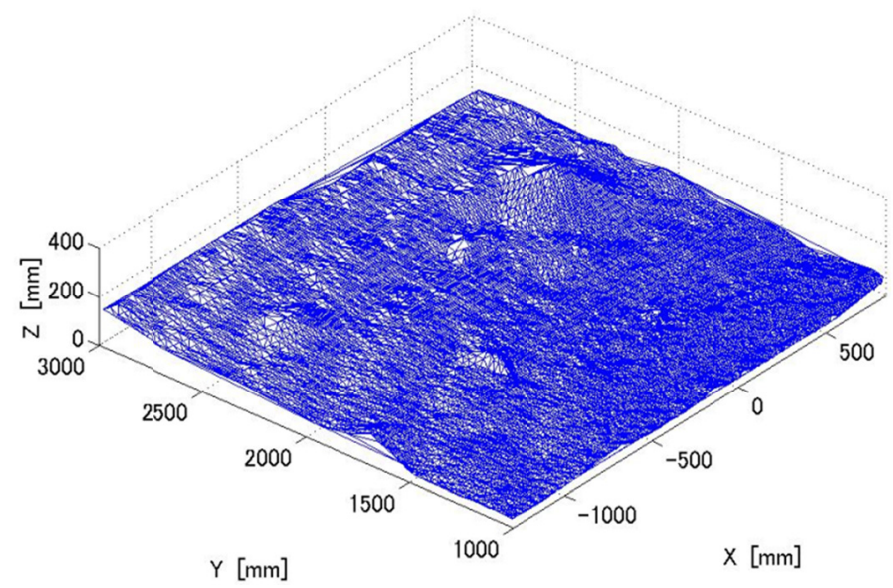

Fig. 8 Terrain surface covered with triangular polygons 


\section{$4 \cdot 2$ 実システムにおける表面形状推定精度の定量化手法とその実験検証}

図 7(b) と(c)もしくは(d)と(e)のように, 推定精度が全領域で大きく異なる場合は, 三次元図を見れば推定精度の 優劣は明らかである。しかし，推定アルゴリズムの細かな違いが精度に及ぼす影響を調べる場合には，その影響 は小さくまた場所により優劣が逆転することもある，そのため，領域全体に渡る推定精度を定量的に評価する方 法が必要となる。このとき, 計算機シミュレーションであれば, 正確な表面形状と推定された点群との間の対応 関係が明確であるため，推定精度を定量化することは難しくない，しかし実験では，LRF の照射先はローバの位 置や姿勢および照射タイミングに依存するため, 照射点と正しい位置との対応関係は明らかではない. そのため, 計算機シミュレーションで用いた式(2)のように，対応点間のずれを計算することはできない.

そこで, 以下のような手法を考える. まず図7(a)のように, ローバが静止した状態でLRFにより表面形状の点 群データを計測し，これより図 8 のような三角形ポリゴンの三次元地形（基準図）を作成する. 次に，移動中の ローバ上の LRF で表面までの距離を計測すると， $X, Y, Z$ 座標を持つ点群データが得られる. そこで，点群デー 夕の水平方向位置 $(X, Y$ 座標 $)$ に対応する高さ（ $Z^{\prime}$ 座標）を基準図から計算し，これと実験により得られた $Z$ 座 標との差を推定誤差と定義する。この処理は，天体探査ローバに搭載されるような計算能力が限られたオンボー ドコンピュータでリアルタイムに処理することは難しい. しかしオフラインで処理するには難しくなく, 推定ア ルゴリズムを開発する段階でいくつかの手法を比較・評価する際には有用である.

図 9 には，上記の方法で定量化した，実験 1 と 2（それぞれ二回）における誤差の平均值と標準偏差を示す. 誤差の平均值を棒グラフで，標準偏差をエラーバーで表現している．薄青色とオレンジ色の棒グラフは，それぞ れ姿勢補正をしてない場合と姿勢補正をした場合に対応する，ピッチ角のみに誤差を含む実験 1 では，姿勢を補 正することで, 図では誤差の平均絶対值が $300 \mathrm{~mm}$ 程度から平均 $20 \mathrm{~mm}$ 程度まで大幅に減少している. またピッ チ角とロール角両方に誤差を含む実験 2 の場合でも, 補正してない場合では誤差の平均絶対值が約 $55 \mathrm{~mm}$ である のに対して, 補正した場合では平均 $20 \mathrm{~mm}$ まで減少できている.つまり姿勢を補正することにより, 実験に用い た姿勢センサーに対しては誤差の標準偏差をおよそ $20 \mathrm{~mm}$ 程度まで減少できることが示されている.このように, 提案した定量化手法を用いれば，実験条件や推定法の違いが精度に及ぼす影響を定量的に評価することが可能に なる．なお，表面の凹凸により LRFにとって死角となる領域は，ローバの移動／停止にかかわらず測定されない ため，死角にならない領域に対寸るデータだけで定量的評価が行われることになる.

また図 7 と図 9 の結果を図 5 および表 3 と比較することにより, 実験と計算機シミュレーションの間で推定精 度について同じ傾向が得られることが分かる.まず図 7 と図 5 との比較より, 実験と計算機シミュレーションに おいて, 姿勢センサーによる角度補正が有効であることが明らかである. 次に図 9 と表 3 の比較により, ロール 角よりもピッチ角の測定精度の方が再構成される表面起伏に大きく影響を与えるということが分かる. (この理由 として, ロール角誤差の影響が $X=0$ からの距離に比例するのに対し, ピッチ角誤差の影響は LRF からの距離に 比例するため奥側（ $Y$ が大きい側）で大きくなることは先に述べた. ) さらに, 図 9 における補正後の誤差 $20 \mathrm{~mm}$ 程度という值は, 表 3 における角度センサ一誤差 1 度以内の場合の平均䛊差（(i)の $21 \mathrm{~mm}$, (iii)の $27 \mathrm{~mm})$ と同 程度である．実験に用いた姿勢センサーのカタログにおける最大誤差が 1 度であることを考えると，よい一致を 示していると言える. したがって，もし最大誤差が 2 度もしくは 3 度である姿勢センサーで実験を行った場合に も，表 3 で示されたような平均的な誤差が得られると予想される.

以上より, 計算機シミュレーションと実験の間でよい一致が見られるので, 次章では計算機シミュレーション を用いて, 滑り率の推定法について検討する. 


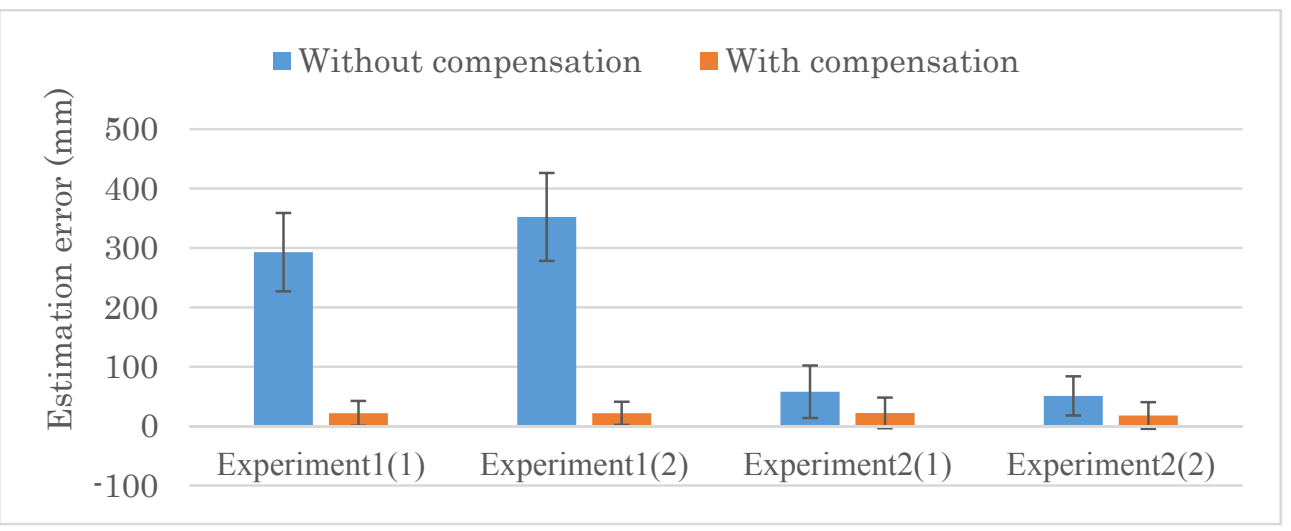

Fig. 9 Estimation error for experiments

\section{5. 車輪の滑り率の推定法}

\section{$5 \cdot 1$ 移動距離推定}

冒頭に述べたように, カメラ画像では得られるが LRFでは得られない情報として, 表面のテクスチャー情報が ある. 天体探査ローバにとって車輪が柔らかい土㙵に埋もれて動けなくなるスタックは，絶対に避けなければな らない，完全にスタックする前には車輪と土壌との滑りの割合（滑り率）が大きくなるので，滑り率の増大をリ アルタイムに捉えることができれば, 後退や方向変換するという対応も可能となる. 滑り率は, “移動したはずの 距離” と“実際の移動距離” の比であるから, 実際の移動距離をLRF から精度よく推定できれば, テクスチャー 情報がなくても支障がない。ここでは，移動中のローバに搭載された LRF を用いて，短い時間間隔でかつ低計算 コストで実際の移動距離を推定する手法について検討する.

LRF は探査ローバと地表面の相対距離を計測するので，スキャンラインが表面のどこに対応するのかを定める ことができれば，ローバの位置を特定できる．また本システムでは，姿勢角センサーによりレーザーの照射方向 を補正するので，ローバが移動中であってもローバ位置の特定が可能となる．得られたスキャンラインが地表面 のどこに対応するのかを決めるために，以下のような手順を考える.

1. ローバが静止した状態で LRF による三次元スキャンを行い，基準となる地表面データ（基準地図と呼ぶ） を取得する.

2. 移動中のローバに搭載された LRF により，スキャンラインを得る.

3. 得られたスキャンラインを基準地図と対応付けすることで, そのスキャンラインが得られたときのローバ の位置を特定する.

4. 3 で得られたローバの位置とそれ以前に特定されたローバの位置から実際の移動距離を推定し, 移動した はずの距離との比から，滑り率を計算する.

スキャンラインからローバ位置を特定する操作を短い時間間隔で繰り返すとすると，3で得られたデータとその 一つ前のデータを添字 $i$ と $i-1$ で表寸とき, その間の移動距離 $d_{i}$ は以下の式で推定できる (図 10).

$$
d_{i} \approx \frac{Y_{i}-Y_{i-1}}{\cos \theta_{r, i}}
$$

ここに， $\theta_{r, i}$ はデータを取得した時刻におけるローバのピッチ姿勢角である.この移動距離を用いて，この時刻 における滑り率 $s_{i}$ は以下のように推定できる.

$$
s_{i}=1-\frac{\sum_{k=i-n}^{i} d_{k}}{\sum_{k=i-n}^{i} \bar{d}_{k}}
$$




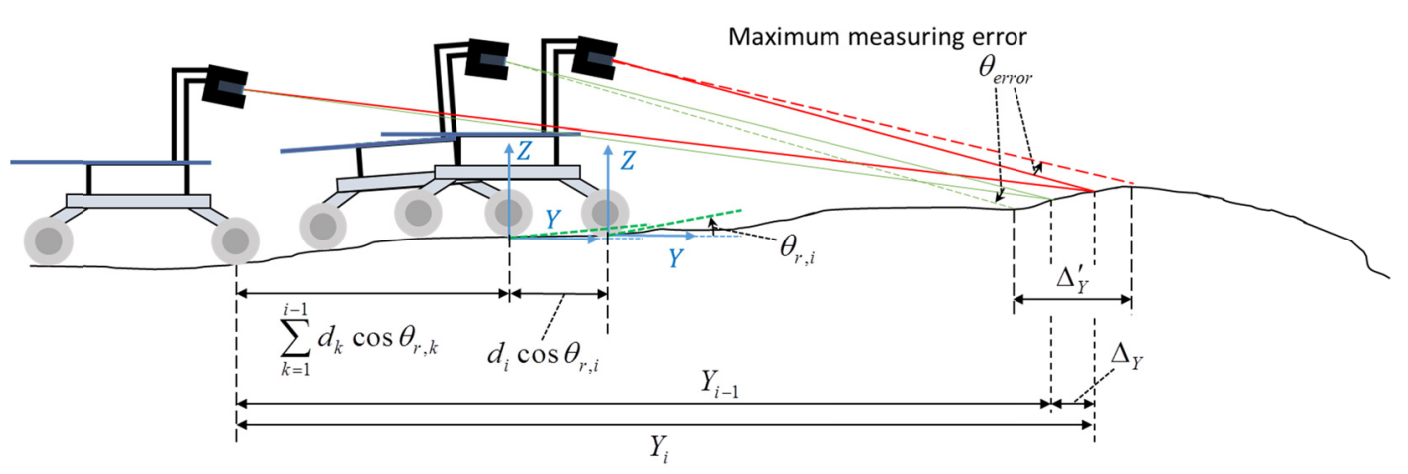

Fig. 10 Estimation concept for travel distance

ここに, $\bar{d}_{i}$ は移動したはずの距離であり, 直前データとの差分に基づく推定值のばらつきを緩和するために, $n$ 個分のデータを用いるようにしている. また，より安定した推定精度を得るためには， $n$ 個分のデータを用いて 平滑化することも考えられる.

\section{$5 \cdot 2$ ローバ位置の特定手法}

ローバ位置は，得られた点列データ（スキャンライン）を基準地図に対して位置合わせをすることにより推定 する. この操作を天体探査ローバに搭載されるコンピュータで短時間に処理できれば，スタックの予兆である滑 り率の増加を捉えることができる. 異なった視点から計測される複数の点群に対する位置合わせ手法としては,

Besl ら (Besl and McKay, 1992) より最初に提案された ICP (Iterative Closest Point) アルゴリズムが知られている. これは，点群を構成する各点に対して基準の点群における最近傍点を探索し，対応点間距離の総和を最小にする ように位置合わせする．しかし点群データが多い場合，計算量も非常に多くなる．そこで Simon ら (Simon et al., 1994) 及び Bergevin ら (Bergevin et al., 1996) らは, 対応付けの高速化を目指して k-d tree と呼ばれる空間分割法や Newton 法による収束速度の向上を研究した. しかし，これらの手法では対応付けデータが完全である（誤差を含 まない)ことを前提としているため, 姿勢角が不規則に変動する移動中ローバ上の LRF で得られるスキャンライ ンへの適用は難しい，そこで本研究では，天体探査ローバの移動速度が非常に遅いことに着目し，基準地図にお ける探査範囲を限定することで高速処理を可能にする．さらに高速化・低計算負荷化を目指して，スキャンライ ンのすべてのデータを用いるのではなく，その中の特徵点だけを抽出して基準地図と対応付けをする手法を提案 する.

基準地図との対応付けにおいては，以下の点に注意しなければならない，まず，ローバの姿勢変動がなく表面 も平坦である場合, LRF のスキャンにより得られるデータ点群は表面上に平行な直線群を構成する. しかし凹凸 がある不整地の表面では，一つのスキャンラインは直線を構成せず，スキャンライン間の間隔も地形に応じて異 なる．また，基準地図を構成したときと移動中ではローバの位置・姿勢が違うため，レーザーのスキャン面も基 準地図を構成したときのレーザー平面と平行ではない，特にロール角に変動が生じると，スキャン面はローバの 手前から奥行きに向けて傾いた平面となり, 得られるスキャンラインは（図7(e)のように）傾いた線となる.こ れらに加えて, レーザーが照射されるタイミングもずれるため, 得られたスキャン点のデータ $(X, Y, Z$ 座標) を 基準地図と直接対応付けることはできない. また対応付けのために，4・2 節で示したように三角形ポリゴンの三 次元地形を構成し $X, Y$ 座標を合わせてから $Z$ 座標を対応付けすることは考えられるが, 計算時間の観点から滑り 率を短時間で推定するには適していない. 


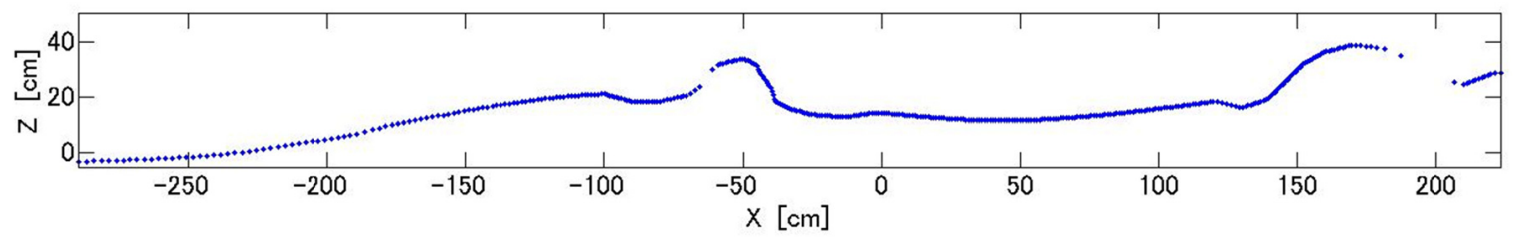

(a) Scan line data projected on XY plane

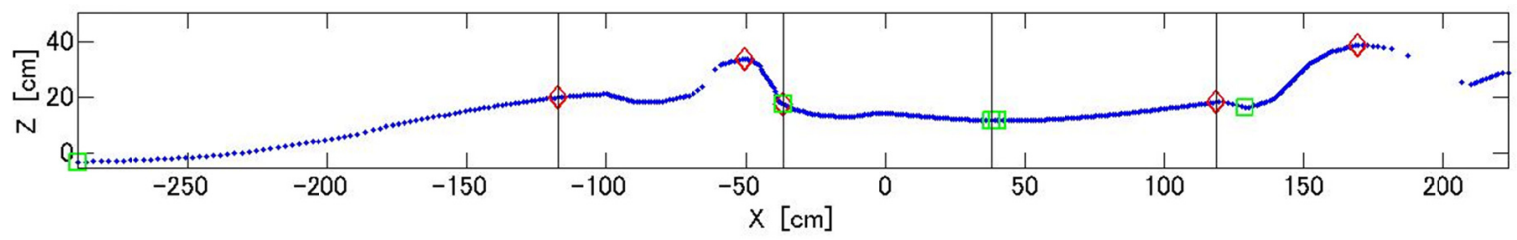

(b) Feature points extracted from divided scan line data

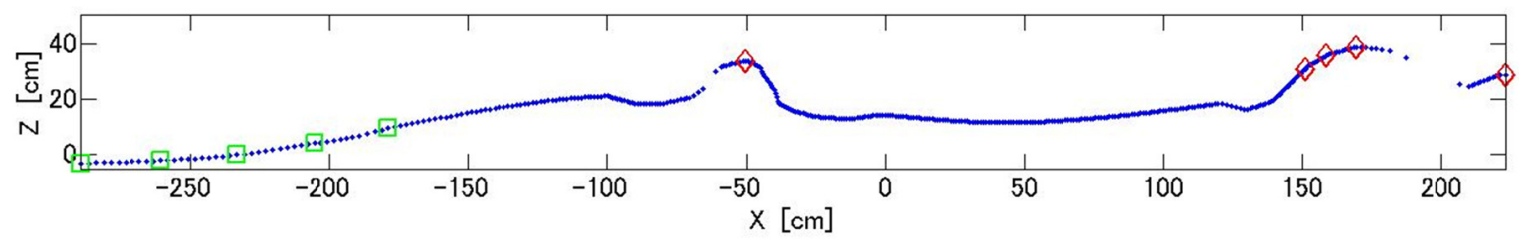

(c) Feature points specified from global scan line data

Fig. 11 Specification of feature points from a scan line

そこでまず，3·1 節で述べたように，パン方に 1 周する間はローバの姿勢が変化しないと仮定すれば，レー ザーは三次元空間内を一つの平面に沿ってスキャンする（もし 1 周する間にローバの姿勢が変化した場合は，そ のスキャンラインを用いた移動距離の推定は行わない，LRF は 1 秒間に 20 回転するので，仮定を満たしたデー タを用いるとしても十分短い間隔で推定できるはずである.）一つのスキャンラインには，パン方向に 0.25 度お きの位置データが得られるので，すべてのデータを用いた対応付けは計算量・計算時間の増加をもたらす.そこ で，スキャンラインの一部のデータだけを選択して対応付けを行う。このとき，スキャンラインの特徴を残した データの選択ができれば，推定誤差を小さくすることが期待できる．ただし上に述べたように，スキャン平面は ローバ位置・姿勢に依存するため，その面内での三次元データ（ $X, Y, Z$ 座標）と，基準地図作成時の三次元デー タとの間には直接的な対応関係はない，そこで計算を高速化・簡単化するという観点から，まずスキャンライン データを $X Z$ 面に投影して特徵点（Feature points）を抽出し，次に抽出した特徵点を使ってスキャンラインを基準 地図データと対応付けるという二段階の手法を採用する.

まず，三次元スキャンラインを $X Z$ 面に投影し特徴点を選択する手法として，以下の二つの方法を考える.

F-1）スキャンラインの点群をいくつかに分割し，各領域において $Z$ 座標が最大と最小の点を特徵点とし， それらを合わせて特徴点の組を構成する。

F-2）全領域を用いて，まず $Z$ 座標が最大と最小の点を特徵点とする. 次に, その特徽点の近傍を除いて, $Z$ 座標が最大と最小の点を特徵点に加えるという操作を繰り返し, 特徵点の組を構成する.

F-1）の方法では，データの領域を分割すれば簡単に特徵点を抽出できる．F-2）の手法でも，(残った）領域から 最大／最小点を抽出するだけなので処理は非常に簡単である. F-2）において特徴点近傍の定義は, 例えば LRF 分解能の整数倍やローバ車輪の乗り越え限界に基づいて決めることが考えられる. 図 11 は, 次節の計算機シミュ レーションで得られたスキャンラインから 10 個の特徵点を選ぶ方法を示した一例である。(a)は各点の $X, Z$ デー タであり，三次元スキャンラインを $X Z$ 面に投影した凹凸に対応する. (b)は F-1）の方法を適用し，スキャン点 の数が各領域で等しくなるように 5 分割した. 黒線が分割領域の境界を示しており, 各領域における $Z$ 最大・最 小の点をそれぞれ赤色と緑色で示している. (c)は F-2) の方法を用い，特徵点近傍を両側に 5 点ずつの範囲と定 義し, $Z$ 座標の最大点／最小点をそれぞれ 5 つ選んだ結果である.

次に，スキャンライン中の特徵点をどのように基準地図と対応付けするかについて説明する．まずローバ姿勢 と LRF チルト角のデータから，ローバ固定座標系におけるレーザー照射方向を決めることができる，ローバは前 回位置推定をした場所から今回のスキャンまでの時間，所望の速度で動こうとするが，実際には車輪に滑りが生 


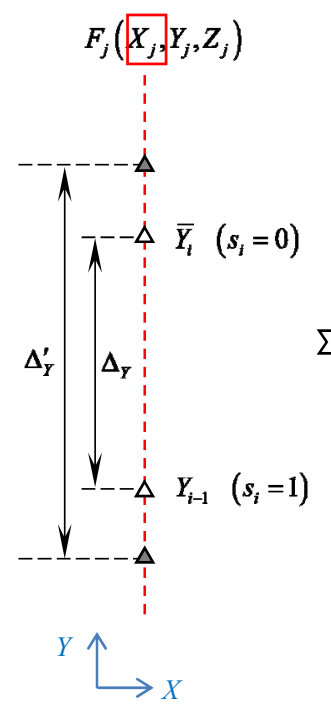

(a) Mapping region

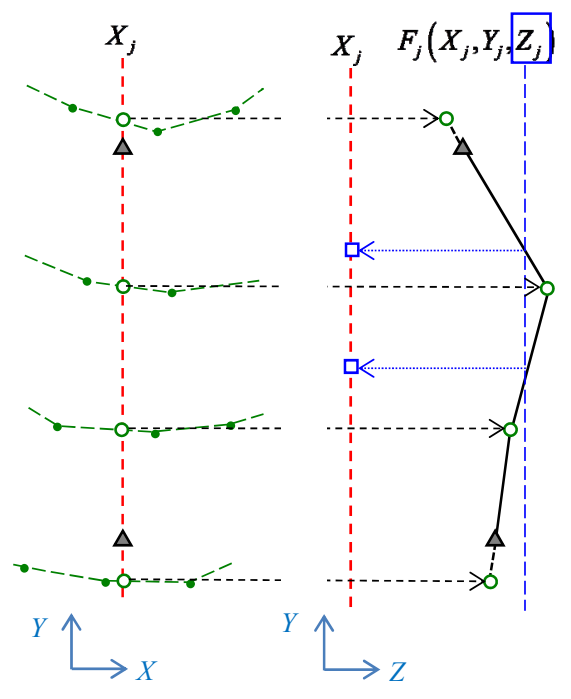

(b) Mapping from $X Y$-plane to $Y Z$-plane

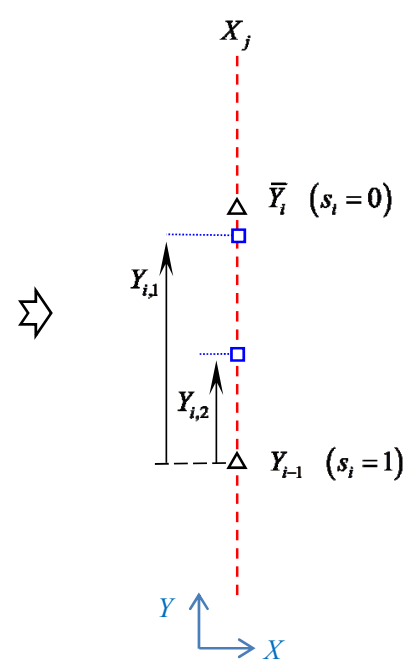

(c) Traversed distance

Fig. 12 Mapping procedure of a feature point to the measured terrain surface

じる可能性がある. そこで, 図 12(a)の赤色破線のように, まずローバ固定座標系における特徵点 $F_{j}$ の $X_{j}$ 座標を 用いて $X Y$ 面上に直線を設定する。もし，車輪が完全に滑り $\left(s_{i}=1\right)$ 全く移動していなければ，前回のローバ位 置とレーザー照射方向からレーザー照射点 $\left(Y_{i-1}\right)$ が決まる，逆に，車輪の滑りがなければ $\left(s_{i}=0\right)$ ， ローバは 前回位置から（設定速度）×（時間）で定まる距離だけ移動するはずであり，これに対応する照射点（ $\bar{Y}_{i} ）$ も定 まる. スキャンラインはこの 2 点間の途中にあるはずであるが, LRF 角度・ローバ姿勢角には誤差 (例えば 1 度) が伴い得る，そこで，誤差の最大值を考慮して，移動中のローバ上で測定されたスキャンラインの存在可能範囲 を $\Delta_{Y}^{\prime}$ に限定する. なおスキャンラインを得る間に LRF 角度・ローバ姿勢角は変化しないとすれば, 存在可能範 囲 $\Delta_{Y}^{\prime}$ の大きさは，スキャンライン中の複数の特徴点に対して等しいことに注意されたい，この範囲内において， 得られたスキャンラインに最も近い凹凸表面を特定できれば，ローバの移動量を推定することができる．次に， 基準地図を作成したときに得られたスキャンラインデータ（レーザー照射点を図 12(b)左図の緑色丸印で示す）か ら， $X Y$ 面における赤破線を横切る点の位置を内挿し (白抜きの緑色丸印), その点とレーザー照射点に対応する $Z$ 座標から図 12(b)右図のような $Y Z$ 断面図を求める. この断面図と特徽点の $Z$ 座標（青色破線）を比較して， ス キャンラインの位置を求める. ただし, 図のように複数の点が対応する場合には, 一旦すべてを候補点（青色四 角）とする．このとき，それぞれの候補点に対する移動距離は，図 12(c)のようになる．その結果，スキャンライ ンには複数の特徵点があり, また一つの特徴点に複数の候補点が存在しうるので, 最終的なスキャンライン対応 付け（Mapping）手法として，次の二つの方法を考える.

M-1）特徵点ごとに移動距離を求める. 複数の候補点がある特徵点については，他の特徴点での移動距離と の差が最も小さくなる候補点を対応点とする.このようにして定めた, 特徵点ごとに移動距離の平均值 を用いて，式(3)から移動距離 $d_{i}$ を求める.

M-2）各特徵点に対して図 12(b)右図のような $Y Z$ 断面図を求めた後, 存在可能範囲 $\Delta_{Y}^{\prime}$ においてスキャンライ ン全体を奥行き方向に同時に移動させたとして, 高度誤差の絶対值の和が最も小さくなるように移動距 離を決定する.

M-2）は表面に存在する凹凸の相対的な位置関係が不変であることを利用した手法であり，M-1）よりも推定誤差 を小さくすることが期待される．また，いずれの方法においても，ローバの移動量 $d_{i}$ を定めれば，式(4)より滑り 率を求めることができる. 
Table 5 Computing time for traveled distance estimation.

\begin{tabular}{c|c|c|c|c}
\hline \hline Partition numbers & 1 & 2 & 5 & 10 \\
\hline F-1)+M-1) & 0.91 & 1.22 & 1.94 & 3.93 \\
\hline F-1)+M-2) & 1 & 1.23 & 2.01 & 2.99 \\
\hline
\end{tabular}

\section{$5 \cdot 3$ 移動距離の推定に要する時間}

ここでは, $5 \cdot 2$ 節で説明した移動距離推定に要する処理時間について検討する. 次節の計算機シミュレーショ ンの結果を考慮して, 特徽点の推定には F-1) を用い, 対応付けの方法は M-1) と M-2) について考える. 特徴点 の数を変化させ，対応付けの方法ごとに推定に要する時間を評価する. 表 5 には，複数回の処理時間を行った平 均值の変化を示す．なお，計算時間は計算機の性能のほかにプログラムなどによっても変わるので，ここではス キャンラインの分割数を 1 とした特徵点の推定 F-1) に対応付け M-2) を組み合わせたときの平均計算時間を単位 時間 1 として，ほかの各条件における計算時間はそれとの相対計算時間として表現している．表より，スキャン ラインの分割数が増えるとともに，計算に要する時間はおよそ線形的に増加するが，M-1）よりも M-2) の方が増 加率は小さく, 特徵点の個数が増や寸場合には M-2)の方が適していることがわかる.

なお，本評価に用いた計算環境 (Matlab2012b, RAM: 8GB, CPU: Core i5m, $1^{\text {st }}$ gen) では, 計算時間 1 は実時間で 約 $0.005 \mathrm{~s}$ であるため, 表中の結果はいずれも LRF が 1 回転に要する時間 $0.05 \mathrm{~s}$ よりも短い. 冒頭に述べたように, 実際の天体探査ローバに搭載されるコンピュータの計算能力は高くないが, この程度の計算ならば容易に実行で きると予想される.

\section{$5 \cdot 4$ 計算機シミュレーションによる比較}

前節までの検討を元に，提案した移動距離の推定手法の精度を評価するために，ここではシミュレーションよ りその効果を検証する．上で述べたように，ローバが移動しながら計測したスキャンラインから移動距離を推定 するには，姿勢角センサーを用いてレーザーの照射方向を精度よく補正する必要がある．しかし，第 3 章および 第 4 章で議論したように, 姿勢角センサーには計測誤差が含まれ，その影響は LRF のチルト角の増加とともに大 きくなることが予想される，そこでまず，これまでと同様にピッチ角／ロール角の姿勢変動を最大 \pm 5 度, 姿勢角 の計測誤差を最大 \pm 1 度として, チルト角を 5 度ごとに変化させ，チルト角と推定された移動距離誤差との関係を 調べる.

結果を図 13 に示寸，予想通り，より遠くをスキャンすることに対応する大きなチルト角に対して，推定精度が 急激に低下している．この原因には，姿勢角の誤差だけでなく，遠いところでは移動前に作成した基準地図の精 密さが低下することが影響している.（ただし，この結果からチルト角を小さな範囲に限定してしまうことは望ま

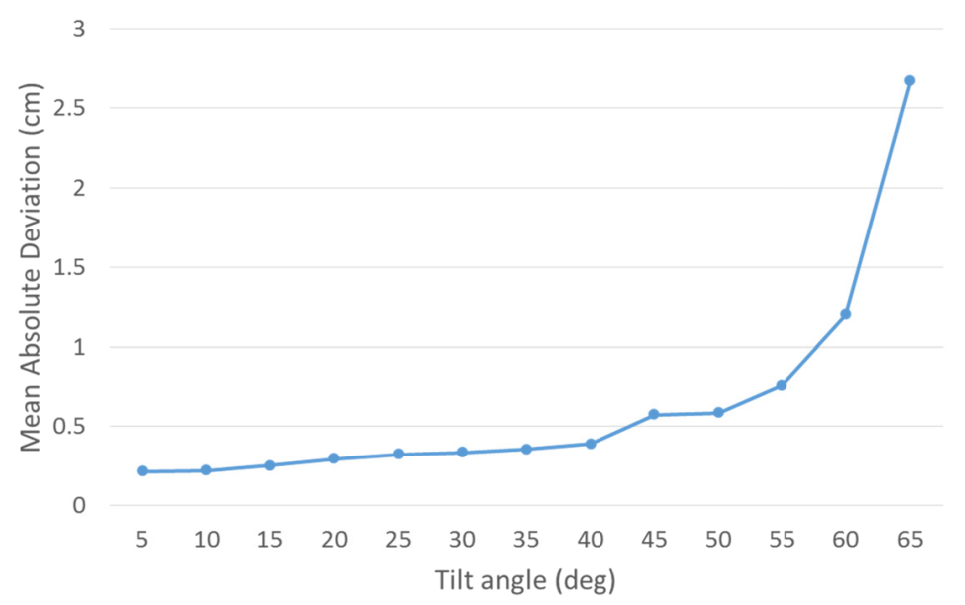

Fig. 13 Mean absolute deviation of estimated result for fixed tilt angles 


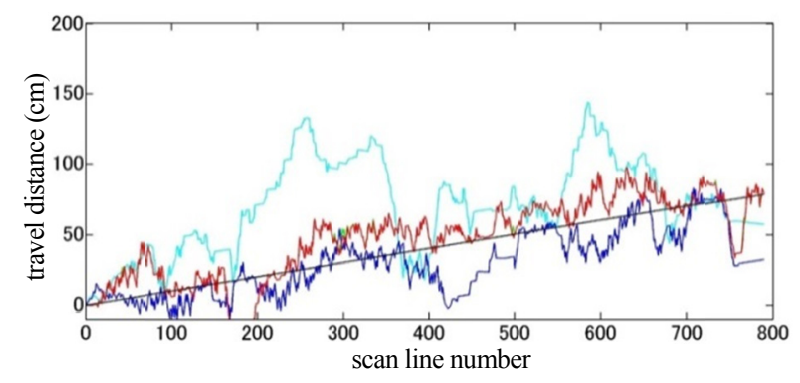

(a) Estimation with 2 feature points

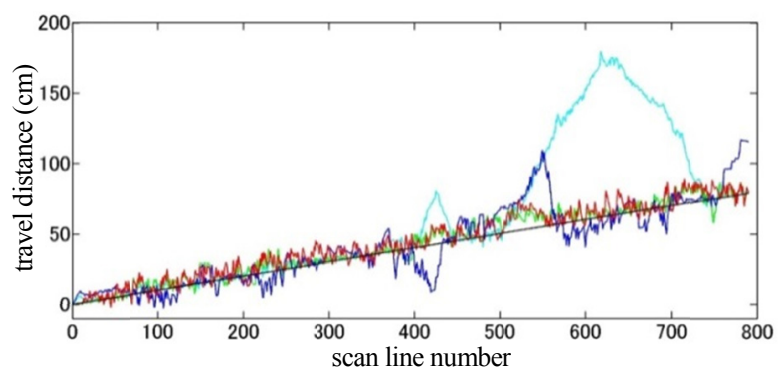

(c) Estimation with 10 feature points

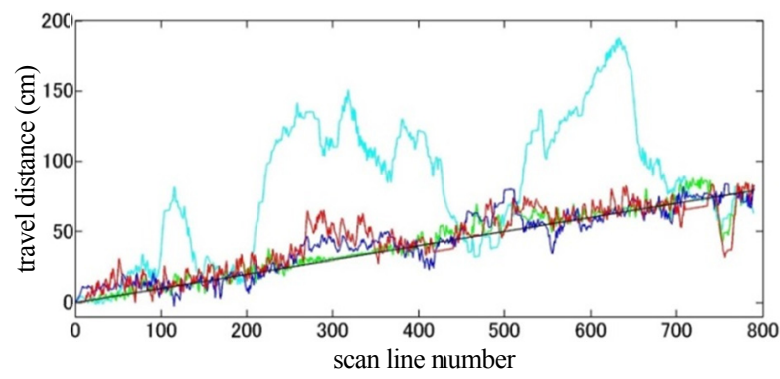

(b) Estimation with 4 feature points

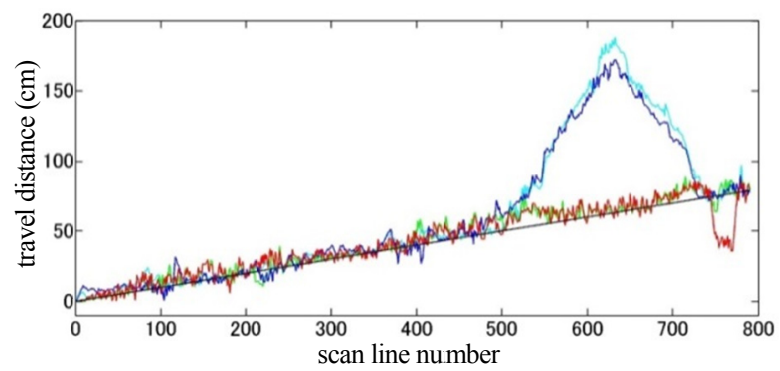

(d) Estimation with 20 feature points

Fig. 14 Comparison of travelled distance estimation from multiple feature points

[legend] $-: \mathrm{F}-1)+\mathrm{M}-1),-\mathrm{F}-2)+\mathrm{M}-1),-\mathrm{F}-1)+\mathrm{M}-2),-\mathrm{F}-2)+\mathrm{M}-2)$

しくない. 天体自律探査ローバには, 安全に移動することだけでなく, 後のミッション遂行のために周囲の表面 データを，できるだけ広範囲に得ることが望まれる．広範囲の環境認識と高精度な滑り率推定という両方の目的 を同時に達成するための LRF チルト角についての検討は，将来的な研究課題である.）

次に LRF のチルト角を変化させながら, 移動距離の推定を行った. 特徴点の個数を変えて, 特徴点の推定法二 つと対応付け方法二つの組合せに対して，計算機シミュレーションにより移動距離を推定する．このとき，表面 起伏に対するシミュレーション結果の一般性を確保寸るために, 表面の傾斜（最大 \pm 5 度）や障害物の数・位置・ サイズは乱数を用いて生成した 10 種類の異なる表面形状を用いた. 図 14 に, 結果の一例を示す. 横軸はスキャ ンラインの番号であり，実際には LRF の 1 回転ごと（1/20 秒毎）の推定は必要ないと思われるが，ここでは一つ のスキャンラインから一つの推定結果を出している．縦軸は，移動距離である．図中の黒い実線はローバの真の 移動量であり, ここでは滑りはないとしている. 4 種類の線は, 特徵点の抽出法 F-1) おるよび F-2) と, 対応付け法 M-1)およびM-2)の組み合わせに対応している. 推定值が大きくずれているところがあるのは，スキャンラインが

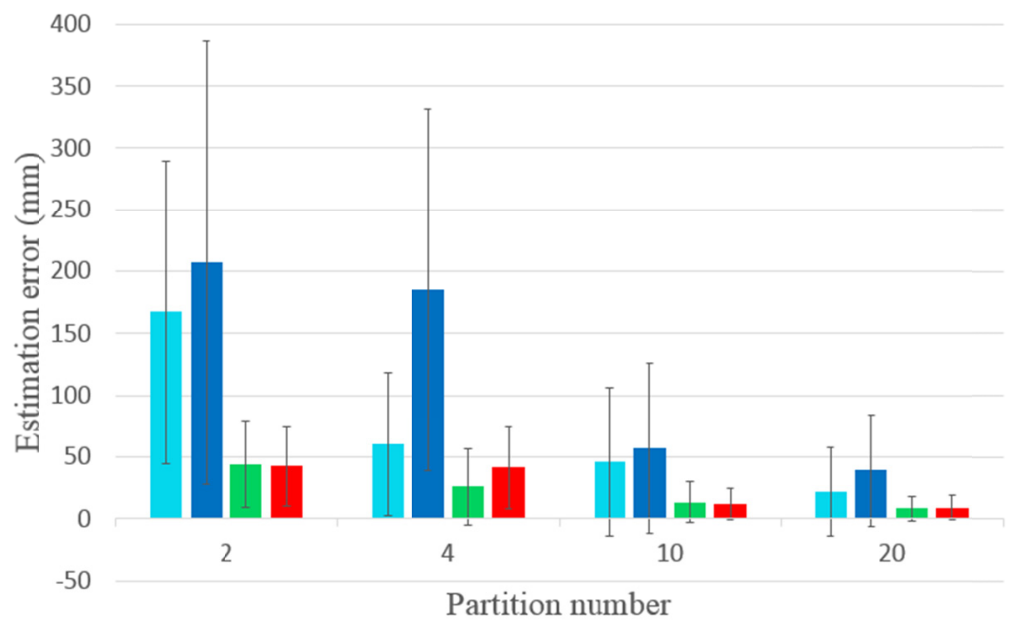

Fig. 15 Estimation error of travelled distance from multiple feature points

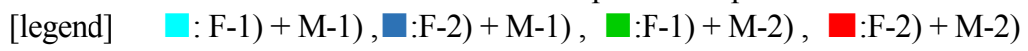




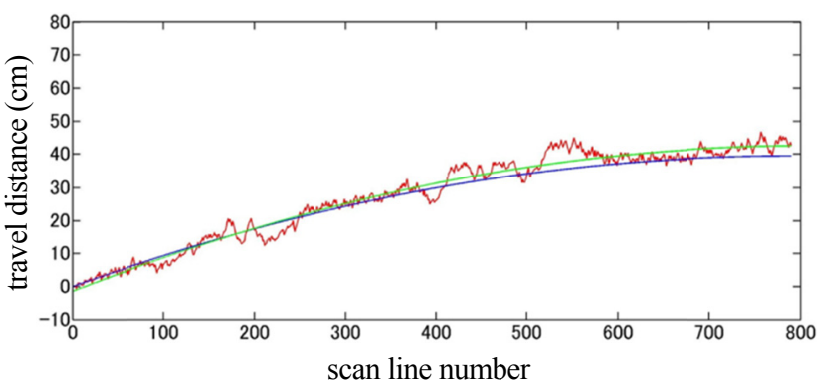

(a) Estimation of travel distance

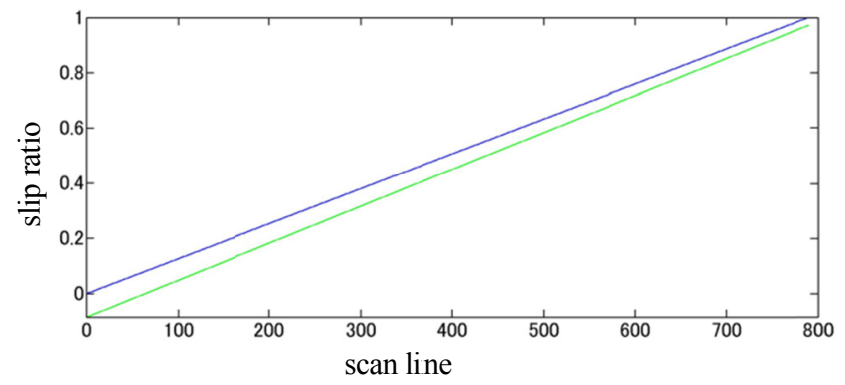

(b) Estimation of slip ratio

Fig. 16 Slip ratio estimation from the mapping procedure when the slip condition changes

ちょうど大きな障害物を横切った影響である.また，10 種類の異なる表面形状に対して得られた推定結果を統計 的に処理したものが, 図 15 である. 棒グラフは, 移動距離の推定誤差の平均值を, エラーバーは標準偏差を示し ており, 横軸方向に特徵点の数を変えた結果をまとめている（特徵点は最大／最小となる点なので，その数は分 割数の 2 倍になる). 結果より, いくつかのことが分かる. まず, 特徵点の数が増えると推定精度は向上している. ただし, 分割数を 5 から 10 にしてもそれほど大きな変化が見られないので, 分割数 5 （特徴点の数は 10）程度あ れば十分であることが分かる，次に，対応付けの方法としては，表面に存在する凹凸の相対的な位置関係が不変 であることを利用した M-2)が，予想通り M-1)よりも精度がよい. 一方で，特徵点の抽出法については，単純に データ数を分割した F-1)も全体から抽出した F-2)もそれほど大きな影響がないことが分かる.

次に，ローバ車輪と表面との間に滑りがあり，その滑りが時間とともに変化する場合を考えた. 図 16 にシミュ レーション結果の一例を示す. (a)は移動距離の履歴を, (b)は滑り率の推定履歴を示す. 横軸はスキャンラインの 番号を表しており，ここでもすべてのスキャンラインに対して移動距離と滑り率を求めた．図中の青線が真值を 示しており，(b)のように滑り率が 0 から 1 まで変化するとした．このとき，移動距離泣(a)の青線となる.これに 対して, 特徵点の抽出 F-1) と対応付け M-2)を用いて移動距離を推定した履歴が(a)中の赤線である. 移動距離が求 まれば滑り率を推定することができるが，直前のデータとの単純な差分では，推定距離誤差の高周波成分を微分 することになって高精度な推定は到底期待できない，実際には得られた移動推定量を平滑化することになるが， 平滑化に用いるデータ数だけでなく，移動速度や特徵点の数なども結果に影響すると予想され，適切な平滑化の 方法については今後の課題としたい。ここでは, 簡単な一つの方法として, 推定した移動量 (赤線) を二次 のス プライン関数で近似し，それから滑り率を推定した結果を(b)中の緑線で示す. 時間とともに滑り率の精度が真值 に近づいていることがわかる.

\section{6. 結 言}

本研究では，遠方の天体を探査する小型ローバが限られたミッション期間中にできるだけ長い距離を移動でき るような自律システムの実現を目指している，そのために，スキャン型LRF と姿勢センサーを組み合わせたシス テムにより，探査ローバが移動しながら周囲の表面形状を認識するシステムを提案した．まず，姿勢センサーを 用いて探査ローバの姿勢を補正寸れば，ローバが移動しながらでも周囲の表面凹凸を再構成できることを計算機 シミュレーションで示した，その後，探査ミッションで検討されているローバシステムに基づき探査ローバ実験 機を製作し，計算機シミュレーションの結果を実験的に検証した．次に，より良い推定アルゴリズムの開発を目 指して, 再構成された表面形状の推定精度を定量的に評価する方法を提案し, 実験結果を用いて推定法の比較結 果を調べた。 さらに，LRFではカメラ画像で得られる表面テクスチャー情報が得られないため，探査ローバが柔 らかい土壌に進入してスタックしてしまう危険性がある. そこで, 移動中に得られるスキャンラインのデータか ら滑り率を推定することを提案し，その手法について説明した。

提案した環境認識システムにより，探査ローバが移動しながら表面形状を認識し，また時々刻々滑り率を推定 できれば，小型探査ローバでも未知環境を長距離移動することが可能になる．より精度の高い滑り率の推定法に ついての検討, およびLRFチルト角についての検討は今後の課題である. 


\section{文献}

Bell, J. F., Squyres, S. W. and Herkenhoff, K. E., Mars exploration rover Athena panoramic camera (Pancam) investigation, Journal of Geophysical Research, Vol. 108, Issue E12 (2003), pp. ROV4.1-ROV4.30 (1 p.3/4).

Bergevin, R., Soucy, M., Gagnon, H. and Laurendeau, D., Towards a general multi-view registration technique, IEEE Transactions on Pattern Analysis and Machine Intelligence, Vol. 18, Issue 5 (1996), pp. 540-547.

Besl, P. J. and McKay, N. D., A method for registration of 3-D shapes, IEEE Transactions on Pattern Analysis and Machine Intelligence, Vol. 14, Issue 2 (1992), pp. 239-256.

Cheng, Y., Maimone, M. W. and Matthies, L. H., Visual odometry on the Mars exploration rovers, IEEE Robotics \& Automation Magazine (2006), pp. 54-62.

Goldberg, S. B., Maimone, M. W. and Matthies, L., Stereo vision and rover navigation software for planetary exploration, Proceedings of the IEEE Aerospace Conference, Vol.5 (2002), pp. 2025-2036.

國井康晴，月惑星表面探査 Rover の火山観測への応用：移動型遠隔無人観測システム:"SCIFIER"の開発(<特集> 無人観測ロボット), 日本惑星科学会誌, Vol. 21, No. 2 (2012), pp. 138-147.

Li, R., Squyres, S. W. and Arvidson, R. E., Initial results of rover localization and topographic mapping for the 2003 Mars exploration rover mission, Journal of Photogrammetric Engineering and Remote Sensing (2005), pp. 1129-1142.

Nguyen, V., Martinelli, A. and Tomatis, N., A comparison of line extraction algorithms using 2D laser rangefinder for indoor mobile robotics, Intelligent Robots and Systems (2005), pp. 1929-1934.

Nuchter, A., Surmann, H. and Lingemann, K., 6D SLAM with an application in autonomous mine mapping, Robotics and Automation, Vol. 2 (2004), pp. 1998-2003.

大槻真嗣, 石上玄也, 嶋田貴信, 久保田孝, 作田真理子, オリチロンアン，大津恭平，清水拓，自立移動ロボッ トによる火山地域の探査活動, 日本惑星科学会誌, Vol.21, No.2 (2012), pp.111-120.

Simon, D., Hebert, M. and Kanade, T., Real-time 3-D pose estimation using a high-speed range sensor, Proceedings of IEEE International Conference on Robotics and Automation, Vol. 3 (1994), pp.2235-2241.

Surmann, H., Nuchter, A., Lingemann, K. and Hertzberg, J., 6D SLAM - preliminary report on closing the loop in six dimensions, Proceedings of the 5th IFAC Symposium on Intelligent Autonomous Vehicles (2004), pp. 5-7.

Thrun, S., Hahnel, D., Ferguson, D., Montemerlo, M., Triebel, R., Bergard, W., Baker, C., Omohundro, Z., Thayer, S. and Whittaker, W., A system for volumetric robotic mapping of abandoned mines, Proceedings of IEEE International Conference on Robotics and Automation, Vol.3 (2003), pp.4270-4275.

上野浩史，宇宙機関における探査ロボットの国際動向，日本ロボット学会誌，Vol. 32, No. 5 (2014), pp. 431-434.

Wulf, O., Lecking, D. and Wagner, B., Robust self-localization in industrial environments based on 3D ceiling structures, Intelligent Robots and Systems (2006), pp.1530-1534.

\section{References}

Bell, J. F., Squyres, S. W. and Herkenhoff, K. E., Mars exploration rover Athena panoramic camera (Pancam) investigation, Journal of Geophysical Research, Vol. 108, Issue E12 (2003), pp. ROV4.1-ROV4.30 (1 p.3/4).

Bergevin, R., Soucy, M., Gagnon, H. and Laurendeau, D., Towards a general multi-view registration technique, IEEE Transactions on Pattern Analysis and Machine Intelligence, Vol. 18, Issue 5 (1996), pp. 540-547.

Besl, P. J. and McKay, N. D., A method for registration of 3-D shapes, IEEE Transactions on Pattern Analysis and Machine Intelligence, Vol. 14, Issue 2 (1992), pp. 239-256.

Cheng, Y., Maimone, M. W. and Matthies, L. H., Visual odometry on the Mars exploration rovers, IEEE Robotics \& Automation Magazine (2006), pp.54-62.

Goldberg, S. B., Maimone, M. W. and Matthies, L., Stereo vision and rover navigation software for planetary exploration, Proceedings of the IEEE Aerospace Conference, Vol.5 (2002), pp. 2025-2036.

Kunii, Y., Development of tele-operated mobile intelligence system: "SCIFIER" for observation and exploration in volcanic area (<Special issue $>$ Unmanned observation robots), Journal of Planetary People, Vol. 21, No. 2 (2012), pp. 138-147 (in Japanese).

Li, R., Squyres, S. W. and Arvidson, R. E., Initial results of rover localization and topographic mapping for the 2003 Mars exploration rover mission, Journal of Photogrammetric Engineering and Remote Sensing (2005), pp. 1129-1142.

Nguyen, V., Martinelli, A. and Tomatis, N., A comparison of line extraction algorithms using 2D laser rangefinder for indoor 
mobile robotics, Intelligent Robots and Systems (2005), pp. 1929-1934.

Nuchter, A., Surmann, H. and Lingemann, K., 6D SLAM with an application in autonomous mine mapping, Robotics and Automation, Vol. 2 (2004), pp. 1998-2003.

Otsuki, M. Ishigami, G., Shimada, T., Kubota, T., Sakuta, M., Ann, O., Otsu, K. and Shimizu, T., Activity of autonomous exploration rover in volcanic region, Yuseijin, The Japanese Society for Planetary Sciences, Vol.21, No.2 (2012), pp.111-120 (in Japanese).

Simon, D., Hebert, M. and Kanade, T., Real-time 3-D pose estimation using a high-speed range sensor, Proceeds of IEEE International Conference on Robotics and Automation, Vol. 3 (1994), pp.2235-2241.

Surmann, H., Nuchter, A., Lingemann, K. and Hertzberg, J., 6D SLAM - preliminary report on closing the loop in six dimensions, Proceedings of the 5th IFAC Symposium on Intelligent Autonomous Vehicles (2004), pp. 5-7.

Thrun, S., Hahnel, D., Ferguson, D., Montemerlo, M., Triebel, R., Bergard, W., Baker, C., Omohundro, Z., Thayer, S. and Whittaker, W., A system for volumetric robotic mapping of abandoned mines, Proceedings of IEEE International Conference on Robotics and Automation, Vol.3 (2003), pp.4270-4275.

Ueno, H., State of art for planetary robotics on space agencies, Journal of the Robotics Society of Japan, Vol. 32, No. 5 (2014), pp. 431-434 (in Japanese).

Wulf, O., Lecking, D. and Wagner, B., Robust self-localization in industrial environments based on 3D ceiling structures, Intelligent Robots and Systems (2006), pp.1530-1534. 